\title{
UDC 539.3+620.178.7
}

O.A. Mikulich, $\mathrm{PhD}$, Assoc.Prof., V.I. Shvab'yuk, DSc, Prof.

Lutsk National Technical University, 75 Lvivska Str., 43018 Lutsk, Ukraine; e-mail: shyprao@gmail.com

\section{INTERACTION OF WEAK SHOCK WAVES WITH RECTANGULAR MESHES IN PLATE}

О.А. Мікуліч, В.І. Шваб'юк. Взаємодія слабких ударних хвиль з прямокутними отворами у пластинці. У машинобудуванні, будівництві та інших галузях виробництва значна частина процесів включає в себе наявність різноманітних динамічних навантажень, обумовлених технологічними і механічними впливами. Врахування впливів таких навантажень дає можливість точніше оцінити міцність елементів конструкцій чи деталей машин. Мета: Метою роботи є розробка алгоритму розрахунку динамічного напруженого стану пластинок $з$ отворами за дії імпульсного навантаження у вигляді слабкої ударної хвилі. Матеріали $\boldsymbol{i}$ методи: Для розв'язання задачі використано інтегральне та дискретне перетворення Фур'є. Застосування перетворення Фур'є за часом дало можливість звести динамічну задачу плоского деформування до розв'язання скінченної кількості задач на усталені коливання при фіксованих значеннях циклічних частот. У області Фур'є-зображень для дослідження динамічної концентрації напружень використано метод граничних інтегральних рівнянь і апарат теорії функції комплексної змінної. Результати: На основі розробленої методики досліджено зміну розподілу динамічних кільцевих напружень з часом на межі прямокутного отвору. Побудовано часові зрізи полів розподілу напружень за дії імпульсного динамічного навантаження.

Ключові слова: пластинка, напружений стан, нестаціонарна задача.

O.A. Mikulich, V.I. Shvab'yuk. Interaction of weak shock waves with rectangular meshes in plate. In mechanical engineering, building and other industries a significant part of the process includes the presence of various dynamic loads due to technological and mechanical impacts. Consideration of such load effects allows more accurate assessment of the structural elements strength or machine parts. Aim: The aim is to develop an algorithm for calculating of dynamic stress state of plates with meshes for pulse loading in the form of a weak shock wave. Materials and Methods: An integral and discrete Fourier transform were used to solve the problem. An application of Fourier transform by time allowed reducing the dynamic problem of flat deformation to the solution of a finite number of problems for the established oscillations at fixed cyclic frequency values. In the area of Fourier-images the method of boundary integral equations and the apparatus of a complex variable function theory are used to study the dynamic stress concentration. Results: Based on the developed methodology the distribution change of the dynamic circle stress over time on the edge of a rectangular hole is studied. The time sections of stress distribution fields under the influence of pulse dynamic load is constructed.

Keywords: plate, stressed state, nonstationary problem.

Introduction. In engineering, construction and other industries a significant part of the technological processes is associated with dynamic loads. Such activity can be single within the operating cycle as a package pulses or vibration. Each of these loads types can be of shock nature.

Obviously, for the actions of such stresses, especially impulse, stress concentration significantly differs from those occurring under conditions of quasi-static deformation. Research of dynamic problems for bodies with meshes was based on Laplace transform. In [1] using the method in the area of images of series the distribution of dynamic stresses in the plate with rectangular meshes from the effects of the shock load applied to the border was investigated. In [2,3] solving the problem is reduced to the singular and regular integral equations.

In $[4,5]$ solving of dynamic problems in the case of antiplain deformation is performed by finite differences method by time.

In $[6,7]$ to study the dynamic stress state of plates with stress concentrators at antiplain strain the Fourier transform is used.

In [8] the technique of research of dynamic stressed state of plates with meshes at the steady-state oscillations is developed. This technique is based on joint use of boundary integral equations method and the apparatus of the complex variable theory. The numerical realization of the offered technique was made on the basis of a method of mechanical quadratures and collocation. Such approach was efficient when calculating of dynamic stress concentration in the plates weakened by meshes of the irregular shape.

\section{DOI 10.15276/opu.2.49.2016.15}

(C) 2016 The Authors. This is an open access article under the CC BY license (http://creativecommons.org/licenses/by/4.0/). 


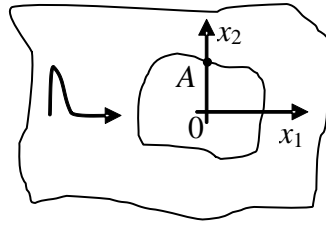

Fig. 1. Scheme of loading of a plate

The aim is to develop an algorithm for calculating of dynamic stress state of plates with meshes for pulse loading in the form of a weak shock wave. This algorithm should be based on boundary integral equations method and apparatus of the complex variable theory.

Materials and methods. Let us consider an infinite isotropic elastic plate, weakened by a hole of any form (fig. 1). We will designate by $D$ the area which is occupied by a plate. Let $L-$ its limiting contour. We will carry an elastic plate to the Cartesian system of coordinates $O x_{1} x_{2}$ which we will place in its gravity center.

According to [3], the equation of the movement of an isotropic plate in movements is written as:

$$
\left(c_{1}^{2}-c_{2}^{2}\right) u_{i},_{i j}-c_{2}^{2} u_{j, i i}+b_{j}=\frac{\partial^{2} u_{j}}{\partial t^{2}},
$$

where $\mathbf{u}(\mathbf{x}, t)=\left\{u_{j}(\mathbf{x}, t)\right\}, j=1,2$ - vector of arbitrary point movement $\mathbf{x}=\left\{x_{1}, x_{2}\right\}$;

$c_{1}=\sqrt{(\lambda+\mu) / \rho}, c_{2}=\sqrt{\mu / \rho}-$ speed expansion and shear of waves respectively;

$\lambda, \mu$ - Lame constants;

$\mathbf{b}=\left\{b_{j}\right\}-$ vector of mass forces;

()$,{ }_{j}$ means for differentiation $x_{j}$;

$t$ - time.

Using Fourier transform [9] to an equation (1) for the time variable $t$

$$
\tilde{f}(x, \omega)=\int_{-\infty}^{\infty} f(x, t) e^{-i \omega t} d t, \quad f(x, t)=\frac{1}{2 \pi} \int_{-\infty}^{\infty} \tilde{f}(x, \omega) e^{i \omega t} d \omega
$$

gets equation:

$$
\left(c_{1}^{2}-c_{2}^{2}\right) \tilde{u}_{i},{ }_{i j}-c_{2}^{2} \tilde{u}_{j, i i}+\tilde{b}_{j}+\omega^{2} \tilde{u}_{j}=0,
$$

which is equivalent to the equation steady-state oscillations with cyclic frequency $\omega$ [3]. The use of Fourier integral transform gives the opportunity to conduct research in the field of images, thereby isolate the effect of the time factor.

Research of dynamic stress state we will conduct in case when plane shock wave waves to the mesh in the plate, that is similarly to [10] defined by the potential:

$$
\varphi(\mathbf{x}, t)=\left\{\begin{array}{cc}
\varphi_{0} f\left(\mathbf{x} / a-c_{1} t / a\right), t \geq 0 \\
0, & t<0
\end{array} \quad \psi(\mathbf{x}, t)=0,\right.
$$

where $\varphi_{0}$ - constant;

$a$ - characteristic size.

Applying to the presentation (4) the integral Fourier transform (2), we get:

$$
\tilde{\varphi}(\mathbf{x}, \omega)=\tilde{\varphi}_{0} a \tilde{f}\left(\omega a / c_{1}\right) e^{-k_{1} \mathbf{x}} / c_{1}=\tilde{\varphi}_{0}(\omega) e^{-k_{1} \mathbf{x}} \quad \tilde{\psi}(\mathbf{x}, \omega)=0,
$$

where $\tilde{\varphi}_{0}(\omega)=\tilde{\varphi}_{0} \frac{a}{c_{1}} \tilde{f}\left(\frac{\omega a}{c_{1}}\right), \tilde{f}(\omega)=\int_{-\infty}^{\infty} f(\tau) e^{-i \omega \tau} d \tau$.

Boundary conditions of the problem in the field of Fourier-images we will write as [3]:

$$
\left.\tilde{\sigma}_{n}\right|_{L}=\tilde{\sigma}(\mathbf{x}, \omega),\left.\tilde{\tau}_{s n}\right|_{L}=\tilde{\tau}(\mathbf{x}, \omega) .
$$

For the case of the first main problem the potential image of general solution for displacements we will choose as [10]: 


$$
\tilde{u}_{i}(\mathbf{x}, \omega)=\int_{L} p_{j}\left(\mathbf{x}^{0}, \omega\right) \cdot U_{j i}^{*}\left(\mathbf{x}, \mathbf{x}^{0}, \omega\right) d s,
$$

where $p_{1}, p_{2}-$ unknown complex potential functions;

$L$ - border of plate area.

Integration along the border is held by the variables $x_{1}^{0}, x_{2}^{0}$, and the $\mathbf{x}^{0}=\left\{x_{1}^{0}, x_{2}^{0}\right\}$. Expressions for images of functions $U_{i j}^{*}$ are chosen accounting the Sommerfeld conditions [10] as [3]:

$$
U_{i j}^{*}=\frac{1}{2 \pi \mu}\left(\psi \cdot \delta_{i j}-\chi \cdot r_{, i} \cdot r_{, j}\right)
$$

where $\quad \psi=K_{0}\left(k_{2} r\right)+\frac{1}{k_{2} r}\left(K_{1}\left(k_{2} r\right)-\frac{c_{2}}{c_{1}} K_{1}\left(k_{1} r\right)\right), \chi=K_{2}\left(k_{2} r\right)-\frac{c_{2}^{2}}{c_{1}^{2}} K_{2}\left(k_{1} r\right)$

$k_{j}=\frac{i \omega}{c_{j}}, j=1,2-$ wave number;

$K_{m}(r), m=0,1,2$ - modified Bessel functions of the third kind (or Macdonald functions);

$r=\sqrt{\left(x_{1}-x_{1}^{0}\right)^{2}+\left(x_{2}-x_{2}^{0}\right)^{2}}$ - distance.

Satisfying the boundary conditions (6), we determine the unknown function on border $p_{1}, p_{2}$, calculating the stresses in the plate by formulas [10]:

$$
\begin{gathered}
\tilde{\sigma}_{n}=\frac{\sigma_{11}+\sigma_{22}}{2}+\frac{1}{2}\left(e^{-2 i \alpha}\left(\frac{\sigma_{11}+\sigma_{22}}{2}+i \sigma_{12}\right)+e^{2 i \alpha}\left(\frac{\sigma_{11}+\sigma_{22}}{2}-i \sigma_{12}\right)\right) ; \\
\tilde{\tau}_{s n}=\frac{i}{2}\left(e^{2 i \alpha}\left(\frac{\sigma_{11}+\sigma_{22}}{2}-i \sigma_{12}\right)-e^{-2 i \alpha}\left(\frac{\sigma_{11}+\sigma_{22}}{2}+i \sigma_{12}\right)\right),
\end{gathered}
$$

where $\alpha$ - the angle between the normal line $\vec{n}$ the plate and the axis $O x_{1}$.

Substituting dependences (7) taking into account the expressions for functions of influence (8) in formulas (9), we will obtain a representation like:

$$
\tilde{\sigma}_{n}=\int_{L} f_{1}(z, \xi) q d \xi+\int_{L} f_{2}(z, \xi) \bar{q} d \bar{\xi} ; \quad \tilde{\tau}_{s n}=\int_{L} g_{1}(z, \xi) q d \xi+\int_{L} g_{2}(z, \xi) \bar{q} d \bar{\xi},
$$

where $q=i \cdot p \cdot d s / d \xi-$ unknown complex functions;

$\xi=x_{1}^{0}+i x_{2}^{0}, z=x_{1}+i x_{2}, p=p_{1}+i p_{2}$;

$f_{i}, g_{i}, i=1,2-$ known function containing Bessel functions of the third kind:

$$
\begin{gathered}
f_{1}=-\frac{i}{4 \pi \mu r}\left((\bar{z}-\bar{\xi}) F-\left(\frac{d z}{d \bar{z}} \frac{(\bar{z}-\bar{\xi})^{2}}{z-\xi} G_{2}+\frac{d \bar{z}}{d z}(z-\xi) G_{1}\right)\right) ; \\
f_{2}=\frac{i}{4 \pi \mu r}\left((z-\xi) F-\left(\frac{d z}{d \bar{z}}(\bar{z}-\bar{\xi}) G_{1}+\frac{d \bar{z}}{d z} \frac{(z-\xi)^{2}}{\bar{z}-\bar{\xi}} G_{2}\right)\right) ; \\
g_{1}=-\frac{1}{4 \pi \mu r}\left(\frac{d z}{d \bar{z}} \frac{(\bar{z}-\bar{\xi})^{2}}{z-\xi} G_{2}-\frac{d \bar{z}}{d z}(z-\xi) G_{1}\right) ; \\
g_{2}=\frac{1}{4 \pi \mu r}\left(\frac{d z}{d \bar{z}}(\bar{z}-\bar{\xi}) G_{1}-\frac{d \bar{z}}{d z} \frac{(z-\xi)^{2}}{\bar{z}-\bar{\xi}} G_{2}\right) \\
F=\psi^{\prime}-\chi^{\prime}-\frac{\chi}{r} ; G_{1}=\psi^{\prime}-\frac{\chi^{\prime}}{2}, G_{2}=\frac{\chi}{r}-\frac{\chi^{\prime}}{2} .
\end{gathered}
$$


The integrands $f_{i}, g_{i}, i=1,2$ at small values of the argument are irregular. Let set their features, using the asymptotic expressions for the Bessel functions of the third kind [12]:

$$
K_{0}(r)=\ln 2-\ln 2-\gamma+O\left(r^{2}\right) ; K_{1}(r)=\frac{1}{r}+\frac{1}{2}\left(-\ln 2+\ln r+\gamma-\frac{1}{2}\right)+O\left(r^{3}\right) ; \quad K_{2}(r)=\frac{2}{r^{2}}-\frac{1}{2}+O\left(r^{2}\right),
$$

where $\gamma$ - Euler's constant.

We obtain, that at $r \rightarrow 0$ functions $\ddot{i} \psi$ and $\chi$ have features of type:

$$
\psi=-\frac{1}{2} \ln r(1+\kappa)+O\left(r^{2}\right) ; \chi=-\frac{1}{2}(1-\kappa)+O\left(r^{2}\right), \kappa=\left(\frac{c_{1}}{c_{2}}\right)^{2} .
$$

Besides, functions $F, G_{1}, G_{2}$ have features of type:

$$
F=-\frac{\kappa}{r}+O\left(r^{2}\right) ; G_{1}=-\frac{1+\kappa}{2 r}+O\left(r^{2}\right) ; G_{2}=-\frac{1-\kappa}{2 r}+O\left(r^{2}\right) .
$$

In the case of plane stressed state $\kappa=(1-v) / 2, v-$ Poisson's ratio.

Considering the above mentioned features of integrand functions, the representation for definition of the functions $f_{i}, g_{i}, i=1,2$ can be written as:

$$
\begin{gathered}
f_{1}=-\frac{i}{4 \pi \mu}\left(\frac{\kappa}{z-\xi}+\frac{1}{2}\left((1-\kappa) \frac{d z}{d \bar{z}} \frac{(\bar{z}-\bar{\xi})}{(z-\xi)^{2}}+\frac{d \bar{z}}{d z} \frac{1+\kappa}{\bar{z}-\bar{\xi}}\right)\right)+f_{1}^{R}(z, \xi) \\
f_{2}=\frac{i}{4 \pi \mu}\left(\frac{\kappa}{\bar{z}-\bar{\xi}}+\frac{1}{2}\left(\frac{d z}{d \bar{z}} \frac{1+\kappa}{z-\xi}+(1-\kappa) \frac{d \bar{z}}{d z} \frac{z-\xi}{(\bar{z}-\bar{\xi})^{2}}\right)\right)+f_{2}^{R}(z, \xi) \\
g_{1}=\frac{1}{8 \pi \mu}\left((1-\kappa) \frac{d z}{d \bar{z}} \frac{\bar{z}-\bar{\xi}}{(z-\xi)^{2}}-\frac{d \bar{z}}{d z} \frac{1+\kappa}{\bar{z}-\bar{\xi}}\right)+g_{1}^{R}(z, \xi) ; \\
g_{2}=-\frac{1}{8 \pi \mu}\left(\frac{d z}{d \bar{z}} \frac{1+\kappa}{z-\xi}-(1-\kappa) \frac{d \bar{z}}{d z} \frac{z-\xi}{(\bar{z}-\bar{\xi})^{2}}\right)+g_{2}^{R}(z, \xi),
\end{gathered}
$$

where the functions $f_{i}^{R}, g_{i}{ }^{R}, i=1,2$ are regular functions.

We apply the Sokhotski-Plemelj formula [10] at the boundary transition in dependences (10) with consideration of the obtained representations. As a result of these changes we obtain the system of integral equations to find the unknowns at functions border $q, \bar{q}$ :

$$
\begin{gathered}
\operatorname{Re} \frac{q}{2}-\operatorname{Im}\left(A_{1} \int_{L} \frac{q d t}{z-\xi}+\frac{d z}{d \bar{z}}\left(A_{2} \int_{L} \frac{\bar{q} d \bar{\xi}}{z-\xi}+A_{3} \int_{L} \frac{(\bar{z}-\bar{\xi}) q}{(z-\xi)^{2}} d \xi\right)\right)+\int_{L} f_{1}^{R}(z, \xi) q d \xi+\int_{L} f_{2}^{R}(z, \xi) \bar{q} d \bar{\xi}=\tilde{\sigma} ; \\
\operatorname{Im} \frac{q}{2}-\operatorname{Re}\left(\frac{d z}{d \bar{z}}\left(A_{2} \int_{L} \frac{\bar{q} d \bar{\xi}}{z-\xi}+A_{3} \int_{L} \frac{\bar{z}-\bar{\xi}}{(z-\xi)^{2}} q d \xi\right)\right)+\int_{L} g_{1}{ }^{R}(z, \xi) q d \xi+\int_{L} g_{2}{ }^{R}(z, \xi) \bar{q} d \bar{\xi}=\tilde{\tau} ;
\end{gathered}
$$

where $A_{1}=\frac{1+v}{4 \pi v}, A_{2}=\frac{3-v}{4 \pi}, A_{3}=\frac{1+v}{4 \pi}-$ the constants defined for a case of flat stressed state;

$\tilde{\sigma}, \tilde{\tau}-$ known functions that are based on representation (5);

$f_{i}^{R}, g_{i}{ }^{R}, i=1,2$ - known regular functions.

Obtained system of integral equations (11) we solve numerically, using method of mechanical quadratures and collocation [12]. For integrals with Cauchy type feature we apply the clarified quadrature formulas [12]. We obtain a system of linear algebraic equations of the form: 


$$
\begin{aligned}
& \frac{q_{s}+\bar{q}_{s}}{4}+\sum_{n=1}^{N} f_{1}\left(z_{s}, \xi_{n}\right) q_{n} g_{n}^{\prime}+\sum_{n=1}^{N} f_{2}\left(z_{s}, \xi_{n}\right) \bar{q}_{n} \bar{g}^{\prime}=\Phi_{1 s} ; \\
& \frac{q_{s}-\bar{q}_{s}}{4 i}+\sum_{n=1}^{N} g_{1}\left(z_{s}, \xi_{n}\right) q_{n} g_{n}^{\prime}+\sum_{n=1}^{N} g_{2}\left(z_{s}, \xi_{n}\right) \bar{q}_{n} \bar{g}_{n}^{\prime}=\Phi_{2 s} ;
\end{aligned}
$$

where $\xi_{n}=g\left(\varphi_{n}\right), z_{s}=g\left(\varphi_{s}\right), \varphi_{n}=h n, \varphi_{s}=\varphi_{n}+\frac{h}{2}, h=\frac{2 \pi}{N}$,

$g(\varphi)$ - parametric boundary setting $L$;

$\Phi_{1 s}=\tilde{\sigma}\left(\varphi_{s}\right), \Phi_{2 s}=\tilde{\tau}\left(\varphi_{s}\right)$;

$N$-number of nodal points.

The calculation of circular stresses in plate held numerically based on dependencies obtained from the formulas [10] by allocating irregular components and use of Sokhotski-Plemelj formula at the boundary transition:

$$
\tilde{\sigma}_{\theta}=v \operatorname{Re} \frac{q}{2}-\operatorname{Im}\left(A_{1} \int_{L} \frac{q d \xi}{z-\xi}-\frac{d z}{d \bar{z}}\left(A_{2} \int_{L} \frac{\bar{q} d \bar{\xi}}{z-\xi}+A_{3} \int_{L} \frac{(\bar{z}-\bar{\xi}) q}{(z-\xi)^{2}} d \xi\right)\right)+\int_{L} y_{1}^{R}(z, \xi) q d \xi+\int_{L} y_{1}^{R}(z, \xi) \bar{q} d \bar{\xi}
$$

where $y_{1}^{R}(z, \xi), y_{2}^{R}(z, \xi)$ - functions that do not have features.

Definition of originals of obtained on the basis of formulas (13) stresses was conducted using inverse Fourier transform [9] according to dependences:

$$
\sigma_{\theta}(\mathbf{x}, t)=\frac{1}{2 \pi} \int_{-\infty}^{\infty} \tilde{\sigma}_{\theta}(\mathbf{x}, \omega) e^{i \omega t} d \omega
$$

which at numerical calculation of circular stresses can be implemented based on the discrete Fourier transform, which proved its effectiveness at researches of the dynamic stress condition at antiplane strain [6].

Results. Based on the proposed algorithm will explore the dynamic stress concentration in plate weakened by rectangular mesh with aspect ratio of 3.2. To describe the border of the plate mesh we use the presentation as a series used in the conformal reflection of a circle of radius $a$ to given region [13]:

$$
g(\varphi)=a\left(e^{-i \varphi}+\frac{e^{i \varphi}}{2}-\frac{e^{3 i \varphi}}{8}-\frac{3 e^{5 i \varphi}}{80}-\frac{3 e^{7 i \varphi}}{896}+\frac{5 e^{9 i \varphi}}{768}+\frac{57 e^{11 i \varphi}}{11264}+\ldots\right),
$$

limiting the number of 11 members.

Numerical calculations we will perform for case of modulation of pulse by time in the form of a weak shock wave [6,7]:

$$
f(\tau)=p_{*} \tau^{n_{*}} e^{-\alpha_{*} \tau}, \tau>0, n_{*} \geq 0,
$$

where $\tilde{f}(\omega)=p_{*}\left(n_{*} !\right)\left(\alpha_{*}+i \omega\right)^{-n_{*}-1}$.

In the calculations such values are taken, similar to [6,7], $p_{*}=185 ; n_{*}=2 ; \alpha_{*}=10 ; a=1$. Research carried out for the interval of dimensionless time parameter $T \in\left[0,8 a / c_{1}\right]$.

As calculated by the formula (14) values of circular stresses $\sigma \theta$ images in general are complex, then Fig. 1 shows the dependence of the changes over time of real and imaginary values of dynamic circular stresses: $\sigma_{\theta}^{R}=\operatorname{Re}\left(\sigma_{\theta}\right), \sigma_{\theta}^{I}=\operatorname{Im}\left(\sigma_{\theta}\right)$, calculated at $A$ point of a border. The calculation results shown in Figure 1 were made at a value of Poisson's ratio $v=0.3$ and $N=300$ of nodal points on the border of the plate.

Based on Fig. 1 it can be analyzed the distribution of weak shock waves in the plate, that come to the mesh border with time. Increasing of the values of dynamic stresses components $\sigma_{\theta}^{R}$ and $\sigma_{\theta}^{I}$, that starts from $T=0.22 a / c_{1}$, corresponds to "coming" to "end" of mesh of disturbing impact $\varphi(\mathbf{x}, \tau)$. 
Further growth of stresses in the plate is associated with the spreading of reflected and rereflected pulses from the edges of the mesh. Fig. 1 shows that the intensity of the shock wave rapidly decreases at reflection from the borders of the mesh. The main influence on the dynamic plastic stress state has the main wave and the first reflected wave from the right border.

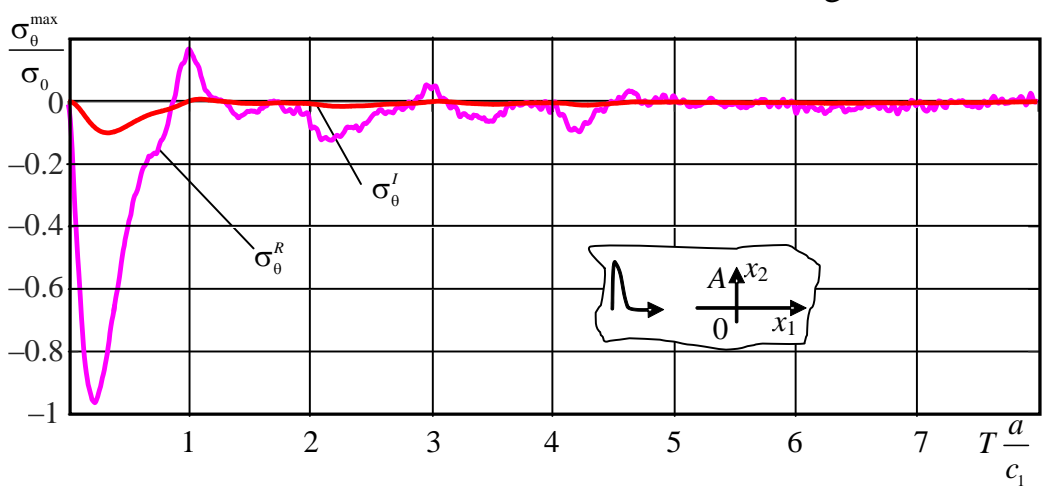

Fig. 1. Distribution of dynamic stresses in the plate with a rectangular mesh

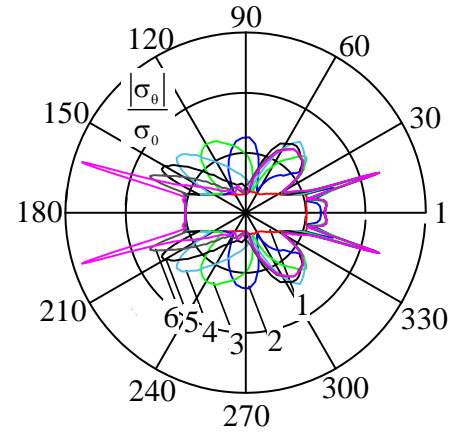

Fig. 2. Dynamic stresses distribution at the border of a circular mesh over time

For a detailed study of unsteady process at the plate over time we build time sections of dynamic stresses distribution along the border of the mesh. The calculation results are shown in Fig. 2 for the time interval $T \in\left[0 ; 1.2 a / c_{1}\right]$ with step $\Delta T=0.2 a / c_{1}$ (curve 1...7).

Fig. 2 shows that under the influence of a weak shock wave the maximum dynamic stresses on the border of the mesh occur in the neighborhood of point A. Further distribution of stresses in the plate essentially depends on defragged waves from its mesh. Numerical calculations showed that the main shock of wave loading will reach the border of the mesh and reflect from it at $T=0.2 a / c_{1}$. Having $T=1.6 a / c_{1}$ the shock wave will reflect from the left side of the border. During the spread of reflected waves in a plate it is seen a significant increase of dynamic stress in angular points.

Having calculated the discrete time representation for movements that are similar to the formula (14) we can analyze a complete picture of unsteady flow wave process at the border of the mesh plate.

Conclusions. The use of integral Fourier transform over time and inverse discrete Fourier transform makes it possible to reduce the dynamic problem of plane deformation to solving the finite number of problems on steady-state oscillations at fixed values of cyclic frequencies. The advantage of the proposed approach is the setting for the incident wave for images area as (5), which makes it possible to calculate using the formula (14) the values of circular stresses for time moments $T_{k} \in[0, T]$, and not just half of them, as it does the calculations based on the discrete Fourier transform [9]. Thus the developed approach based on the method of boundary integral equations and the theory of functions of complex variables in field of Fourier-images makes it possible to calculate the time dependence of dynamic stresses in bodies with meshes for the actions of impulsive dynamic loads.

\section{Література}

1. Гузь, А.Н. Дифракция упругих волн / А.Н. Гузь, М.А. Черевко, В.Д. Кубенко. - К.: Наукова думка, 1978. - 307 с.

2. Banerjee, P.K. Boundary element methods in engineering science / P.K. Banerjee, R. Butterfield. $-2^{\text {nd }}$ Ed. - London: McGraw-Hill, 1994. - 496 p.

3. Brebbia, C.A. Boundary element techniques in engineering / C.A. Brebbia, S. Walker. — London: Butterworth, 1980. - $210 \mathrm{p}$.

4. Mykhas'kiv, V.V. Interaction between rigid-disc inclusion and penny-shaped crack under elastic timeharmonic wave incidence / V.V. Mykhas'kiv, O.M. Khay // International Journal of Solids and Structures. - 2009. - Vol. 46, Issues 3-4. - PP. 602-616. 
5. Саврук, М.П. Новий метод розв’язування динамічних задач теорії пружності та механіки руйнування / М.П. Саврук // Фізико-хімічна механіка матеріалів. - 2003. — № 4. - С. 7-11.

6. Пастернак, Я. Концентрація динамічних напружень біля тонких пружних включень за умов антиплоскої деформації / Я. Пастернак, Г. Сулим, Р. Пастернак // Фізико-математичне моделювання та інформаційні технології. — 2013. - Вип. 18. - С. 157-164.

7. Кунець, Я.І. Динамічна концентрація напружень в околі заглибленого тонкого прямолінійного включення низької жорсткості в умовах антиплоскої деформації / Я.І. Кунець, В.В. Матус, В.В. Пороховський // Математичні методи та фізико-механічні поля. — 2007. — Т. 50, № 1. C. $136-139$.

8. Shvabyuk, V. Stress state of plate with incisions under the action of oscillating concentrated forces / V. Shvabyuk, H. Sulym, O. Mikulich // Acta Mechanica et Automatica. - 2015. - Vol. 9, Issue 3. PP. 140-144.

9. Director, S.W. Introduction to systems theory / S.W. Director, R.A. Rohrer. - Tokyo: McGraw-Hill, 1972. - $441 \mathrm{p}$.

10. Божидарник, В.В. Елементи теорії пружності / В.В. Божидарник, Г.Т. Сулим. — Львів: Світ, 1994. - $580 \mathrm{c}$.

11. Саврук, М.П. Двумерные задачи упругости для тел с трещинами / М.П. Саврук. - К.: Наукова думка, 1981. - 324 с.

12. Abramowitz, M. Handbook of mathematical functions with formulas, graphs, and mathematical tables / M. Abramowitz, I.A. Stegun. - Mansfield Centre, CT: Martino Publishing, 2014. - 1046 p.

13. Савин, Г.Н. Распределение напряжений около отверстий / Г.Н. Савин. - К.: Наукова думка, 1968. $-887 \mathrm{c}$.

\section{References}

1. Guz', A.N., Kubenko, V.D., \& Cherevko, M.A. (1978). Diffraction of Elastic Waves. Kyiv: Naukova Dumka.

2. Banerjee, P.K., \& Butterfield, R. (1994). Boundary Element Methods in Engineering Science $\left(2^{\text {nd }}\right.$ Ed.). London: McGraw-Hill.

3. Brebbia, C.A., \& Walker, S. (1980). Boundary Element Techniques in Engineering. London: Butterworth.

4. Mykhas'kiv, V.V., \& Khay, O.M. (2009). Interaction between rigid-disc inclusion and penny-shaped crack under elastic time-harmonic wave incidence. International Journal of Solids and Structures, 46(3-4), 602-616. DOI:10.1016/j.ijsolstr.2008.09.005

5. Savruk, M.P. (2003). New method for the solution of dynamic problems of the theory of elasticity and fracture mechanics. Materials Science, 39(4), 465-471. DOI:10.1023/B:MASC.0000010922.84603.8d

6. Pasternak, I., Sulym, H., \& Pasternak, R. (2013). Dynamic stress concentration at thin elastic inclusions under the antiplane deformation. Physico-Mathematical Modelling and Informational Technologies, 18, 157-164.

7. Kunets, Ya.I., Matus, V.V., \& Porokhovs'kyy, V.V. (2007). Dynamic stress concentration in the vicinity of submerged thin plane inclusion of low rigidity under antiplane strain. Mathematical Methods and Physicomechanical Fields, 50(1), 136-139.

8. Shvabyuk, V., Sulym, H., \& Mikulich, O. (2015). Stress state of plate with incisions under the action of oscillating concentrated forces. Acta Mechanica et Automatica, 9(3), 140-144. DOI:10.1515/ama-2015-0023

9. Director, S.W., \& Rohrer, R.A. (1972). Introduction to Systems Theory. Tokyo: McGraw-Hill.

10. Bozhydarnyk, V.V., \& Sulym, H.T. (1994). Elements of the Theory of Elasticity. Lviv: Svit.

11. Savruk, M.P. (1981). Two-Dimensional Elasticity Problems for Bodies with Cracks. Kyiv: Naukova Dumka.

12. Abramowitz, M., \& Stegun, I.A. (2014). Handbook of Mathematical Functions with Formulas, Graphs, and Mathematical Tables. Mansfield Centre, CT: Martino Publishing.

13. Savin, G.N. (1970). Stress Distribution around Holes. Washington, D.C.: NASA.

Received May 13, 2016

Accepted June 25, 2016 